\title{
Clinical and sociodemographic risk factors associated with the development of second primary cancers among postmenopausal breast cancer survivors
}

\author{
Stacyann Bailey ( $\sim$ stacyann.bailey@umass.edu ) \\ University of Massachusetts https://orcid.org/0000-0001-9013-2469 \\ Charlotte Ezratty \\ Icahn School of Medicine at Mount Sinai \\ Grace Mhango \\ Icahn School of Medicine at Mount Sinai \\ Jenny J. Lin \\ Icahn School of Medicine at Mount Sinai
}

\section{Research Article}

Keywords: breast cancer survivors, second primary cancer, aromatase inhibitor, comorbidities, medications

Posted Date: May 25th, 2022

DOI: https://doi.org/10.21203/rs.3.rs-1028396/v2

License: (c) (1) This work is licensed under a Creative Commons Attribution 4.0 International License.

Read Full License 


\section{Abstract \\ Introduction}

: Advances in breast cancer (BC) diagnosis and treatment have increased the number of long-term survivors. Consequently, primary BC survivors are at a greater risk of developing second primary cancers (SPCs). The risk factors for SPCs among BC survivors including sociodemographic characteristics, cancer treatment, comorbidities, and concurrent medications have not been comprehensively examined. The purpose of this study is to assess the incidence and clinicopathologic factors associated with risk of SPCs in BC survivors.

\section{Methods}

We analyzed 171, 311 women with early-stage primary BC diagnosed between January 2000-December 2015 from the Medicare-linked Surveillance Epidemiology and End Results (SEER-Medicare) database. SPC was defined as any diagnosis of malignancy occurring within the study period and at least six months after primary BC diagnosis. Univariate analyses compared baseline characteristics between those who developed a SPC and those who did not. We evaluated the cause-specific hazard of developing a SPC in the presence of death as a competing risk.

\section{Results}

Of the study cohort, $21,510(13 \%)$ of BC survivors developed a SPC and BC was the most common SPC type (28\%). The median time to SPC was 44 months. Women who were white, older, and with fewer comorbidities were more likely to develop a SPC. While statins [hazard ratio (HR) 1.066 (1.023-1.110)] and anti-hypertensives [HR 1.569 (1.512-1.627)] increased the hazard of developing a SPC, aromatase inhibitor therapy [HR 0.620 (0.573-0.671)] and bisphosphonates [HR $0.905(0.857-0.956)]$ were associated with a decreased hazard of developing any SPC, including non-breast SPCs.

\section{Conclusion}

Our study shows that specific clinical factors including type of cancer treatment, medications, and comorbidities are associated with increased risk of developing SPCs among older BC survivors. These results can increase patient and clinician awareness, target cancer screening among BC survivors, as well as developing risk-adapted management strategies.

\section{Introduction}

Breast cancer (BC) accounts for nearly one in three cancer cases diagnosed in women (1). Early detection as well as improved management have contributed to the increase in survival rates of BC patients. As a 
result, longer life expectancy is accompanied by increased risk of developing a second primary cancer (SPC), defined as malignant tumors with differing pathologic morphologies, and are not metastases from the initial primary cancer $(1,2)$.

The incidence of SPCs among women with primary BC have been inconclusive, ranging from $4-17 \%$, with varying follow up times (1). Though prior studies show that $B C$ survivors are more susceptible to developing a SPC $(3,4)$, it has been difficult to quantify that risk, and identify specific factors that may predispose some BC survivors to developing SPCs. The American Cancer Society recommends annual mammography screenings for the general population as well as specific guidelines for those with a family history of $\mathrm{BC}$ or women with genetic mutations. However, there is currently not enough evidence for specific BC screening recommendations based on having a personal history of BC. There are also no comprehensive screening guidelines for other types of cancers in $\mathrm{BC}$ survivors.

The purpose of this study is to (1) assess the incidence and types of SPCs among an extensive cohort of older BC survivors and (2) identify clinical and sociodemographic factors associated with the development of SPCs. Our study will aid in improving clinician and patient awareness of SPCs in BC survivors and guide discussions for developing risk-adapted management strategies.

\section{Materials And Methods}

\section{Data Sources}

Study participants were selected from the Surveillance, Epidemiology and End Results registry linked to Medicare claims record (SEER-Medicare). We excluded individuals in healthcare maintenance organizations (HMOs) and those without Medicare Parts A and B insurance, due to incomplete claims which are needed to assess comorbidities and cancer treatment (e.g., surgery, chemotherapy, radiation therapy). We excluded individuals without Medicare Part D claims data which were needed to ascertain prescription medication use.

\section{Study Population}

We identified patients $>66$ years of age who were diagnosed with primary BC between January 1, 2000, and December 31, 2015, in the SEER-Medicare database. We only included patients with a pathologically confirmed primary BC diagnosis. Those with diagnoses made at autopsy and with death certificate were excluded. We further limited our cohort to include only female patients, with early stage (0 to III) primary BC.

Sociodemographic variables were extracted from Medicare-linked claims and included age at diagnosis, race/ethnicity, income quartile, county/residency type, marital status, first treatment regimen, comorbidities, and medications. Comorbidity burden was assessed using the recommended $\mathrm{NCl}$ comorbidity index with weights specific for breast cancer. BC treatment (surgery, chemotherapy, and radiotherapy) was extracted using International Classification of Diseases Ninth Revision (ICD-9), and 
Health Care Procedure Coding System (HCPCS) procedural codes. Patients were considered to use the medications of interest (Table 2) if they had used the drug within the year prior to cancer diagnosis until 6 months after diagnosis. Similarly, patients were considered to have specific comorbidities if there was at least one inpatient or two outpatient Medicare claims code for the diagnosis within 1 year prior to cancer diagnosis up until 6 months after primary BC diagnosis. This study was deemed exempt by the Mount Sinai Institutional Review Board.

\section{Study Outcome}

The primary outcome was development of any SPC. We excluded diagnosis claims of BC that occurred within six months of the primary BC to remove what were likely multiple primary tumors.

\section{Statistical Analysis}

We conducted chi-square tests to evaluate differences in sociodemographic and clinical characteristics of patients with and without SPCs. To estimate the effects of covariates on the rate of SPC occurrence, we used a cause-specific hazard model in the presence of competing risk. The time to development of SPC was defined as the time since the initial BC diagnosis, with a delayed entry of 6 months after the primary BC diagnosis, until SPC occurrence, end of follow-up, or death. The 6-month latency period is in line with SEER Solid Tumor Rules which aims to distinguish single from multiple primary tumors. Patients who experienced death as a competing risk and those who did not develop a SPC were censored. Three cause-specific models were developed: all SPCs, breast only as a SPC, and non-breast SPCs. The results are presented as hazard ratios (HR) with corresponding two-sided $95 \%$ confidence intervals $(\mathrm{Cl})$. In all models, Her2/neu data was excluded because it was not recorded by the SEER registry for all years evaluated in this study. All statistical analyses were performed using SAS (version 9.4), with the two-sided significance level set at $p<0.05$.

\section{Results}

\section{Final Cohort Characteristics}

The final cohort of primary early-stage BC survivors included 171,311 women, with a mean age at diagnosis of 75 years. The median follow-up time was 5 years (interquartile range [IQR]: 6.36). SPC development occurred in $12.6 \%$ ( $n=21,510)$ of patients. The total study population consisted of $84 \%$ nonHispanic white, $8 \%$ non-Hispanic Black, and $4 \%$ Hispanic women. Most of the population lived in urban counties (98\%) and $45 \%$ were married. The distribution of primary BC stages was: $18 \%$ stage $0,46 \%$ stage I, $27 \%$ stage II, and $9 \%$ stage III. Sixty-eight percent of primary breast tumors were classified as ductal carcinoma. Most tumors were classified as hormone receptor (HR) positive/Her2 negative (79\%), and only $9 \%$ were triple negative tumors. Surgery occurred in $94 \%$ of the population, while $17 \%$ underwent chemotherapy, and 40\% underwent radiotherapy. Most of the women had an $\mathrm{NCl}$ Comorbidity Index score of $<1(79 \%)$. Antihypertensives and statins were the most prescribed medications used by $33 \%$ and $20 \%$ of the cohort, respectively. 


\section{Types of Second Primary Cancers}

Of the 21,510 patients who developed a SPC, $28 \%$ had a second primary BC (Fig. 2). Lung, colorectal, and urinary cancers comprised $15 \%, 11 \%$, and $10 \%$ of SPC's, respectively. Skin and gynecologic cancers accounted for $6 \%$ and $4 \%$ of SPCs, respectively. Gallbladder/pancreatic and hematologic cancers each occurred in $4 \%$ and $3 \%$ of the patient population, respectively. Other SPCs included liver, gastrointestinal, soft tissue and bone, endocrine, and brain, and collectively accounted for $18 \%$ of the SPCs. The median time between primary BC and SPC diagnosis was 3.67 years (IQR: 5.09).

\section{Factors associated with the development of SPCs}

Unadjusted analysis (Table 1) revealed that SPC cases were more often diagnosed in white patients (12.8\% vs. $12.1 \%$ among black, $11.6 \%$ among Hispanic and $10.2 \%$ among other races), those who were somewhat older ( $13.7 \%$ for $70-79$ years vs. $12.9 \%$ for $66-69$ years), and those with fewer comorbidities $(12.9 \% \mathrm{NCl}$ comorbidity index $<1$ vs. $12.1 \%$ for $\mathrm{NCl}$ comorbidity index $1-2$ and $10.2 \%$ for $\mathrm{NCl}$ comorbidity index $>2$ ). Additionally, married BC survivors (12.9\% vs. $12.3 \%$ ) and those in the highest income quartile $(12.8 \%$ vs. $12.5 \%)$ were more likely to develop SPCs. SPCs also occurred more often with stage 0 vs. stage I disease ( $15.4 \%$ vs. $12.8 \%$ ) and those who underwent surgery $(12.7 \%$ vs. $9.8 \%)$ or radiation therapy (13.5\% vs. $11.9 \%)$. Chemotherapy was not significantly associated with development of SPC ( $p=0.637)$. Additionally, patients who were prescribed medications such as statins, antihypertensives, and thiazolidinediones were more likely to develop a SPC, while those taking aromatase inhibitors were less likely to develop a SPC $(p<0.001$, Table 2$)$.

In multivariable-adjusted models, the hazard of developing any SPC was greater in patients aged 75-79 [HR 1.121 (1.078-1.165)], highest income quartile [HR 1.066 (1.025-1.108)], and with stage IIIC BC compared to stage 0 [HR 1.169 (1.051-1.300)]. Those who had a greater number of comorbidities [HR $0.735(0.690-0.784)]$ had a lower hazard of developing a SPC. However, BC survivors with the following comorbidities had increased hazard of developing any SPC: diabetes [HR 1.363 (1.303-1.426)], renal disease [HR 1.405 (1.333-1.481)], and chronic obstructive pulmonary disease (COPD) [HR 1.760 (1.6991.824)]. We also observed a lower hazard of SPC in patients who were taking bisphosphonates [HR 0.905 (0.857-0.956)] and aromatase inhibitors [HR 0.620 (0.573-0.671)]. Medications such as antihypertensives [HR 1.569 (1.512-1.627)] and statins [HR 1.066 (1.023-1.110)] increased the hazard of SPCs.

In contrast to any SPC, the hazard of developing breast-only SPC was significantly lower in Hispanic BC survivors [HR 0.821 (0.717-0.939)] and higher in those diagnosed with earlier stage BC (stage 0 vs. stage I) [HR 1.434 (1.339-1.536)]. While patients with estrogen receptor (ER) negative status had an increased hazard for BC only SPC [HR 1.442 (1.304-1.595)], patients who received chemotherapy [HR 0.896 (0.820-0.978)] and were taking bisphosphates [HR $0.898(0.812-0.993)]$ as well as thiazolidinediones [HR 0.651 (0.496-0.853)] had a significantly lower hazard. 
Compared to the breast only SPC group, the factors associated with greater hazard for non-breast SPC were somewhat different. The hazard for non-breast SPCs was highest for patients 75-79 years old [HR 1.187 (1.133-1.243)] compared to those 66-69 years old. Patients who underwent chemotherapy [HR 1.097 (1.043-1.151)] or radiation therapy [HR 1.053 (1.017-1.090)] for their initial primary BC had an increased risk of developing a non-breast SPC. We observed a similar trend for decreased hazard of developing a non-BC SPC in patients who were on medications such as aromatase inhibitors [HR 0.635 (0.581-0.694)] and bisphosphonates [HR 0.892 (0.836-0.952)]. An increased hazard of SPC was observed for those with comorbidities such as diabetes [HR 1.443 (1.369-1.521)], renal disease [HR 1.485 (1.398-1.577) and COPD [HR 2.032 (1.953-2.115)].

\section{Discussion}

In this study, we determined the incidence of second primary cancers (SPCs) among early-stage BC survivors and identified several sociodemographic and clinical risk factors associated with the development of SPCs. Using the SEER-Medicare Linked Database with detailed information about Medicare beneficiaries with cancer from 19 United States (US) geographic regions, we found that the incidence of any SPC among older women with primary BC is $13 \%$. Women of white race and those who were married were more likely to develop a SPC. Additionally, hormone receptor (HR) negative primary BC diagnosed at stage 0 , treated with surgery or radiotherapy, were also associated with incidence of SPC.

While older age at BC diagnosis (ages 70-79), was associated with increased development of SPC, we observed a decline in SPC incidence among women $\geq 80$ years after adjusting for competing risk of death which is consistent with other studies (5). Compared to white women, the incidence of any SPC was lower for women of non-Hispanic black, Hispanic, and other races. The higher incidence of SPC among white women may be due to their overall higher survival rates after BC diagnosis or due to increased surveillance practices (6). It is noteworthy that prolonged survival is an independent risk factor for the development of SPC (7). We also observed that married women were more likely to develop a SPC. Patients who are married are more likely to get psychosocial and financial support which may aid in early cancer detection, appropriate treatment, and prolonged survival (8).

We found that the incidence of all SPCs is higher in those with ductal primary BCs, compared to lobular, as well as in triple negative BC. After adjusting for confounders, primary BC histology was not significantly associated with SPC development, however, estrogen receptor (ER) negative cancers specifically conferred a higher risk of all SPCs. Though most studies tend to focus on combined ER/PR hormone receptor status, it has been found that most BRCA1-associated breast cancers, which are susceptible to recurrence, are ER negative (9). In general, HR negative tumors are more likely to be poorly differentiated with increased recurrence rates $(10,11)$. The increased recurrence rates may be explained by carcinogenesis research which demonstrated that BC stem cells are HR negative, and thus patients with HR negative tumors are predisposed to cancer early in the breast cell maturation process (12). As such, patients with HR negative breast tumors have a 10-fold increased risk of developing a second hormone negative tumor, as compared to the general population (12). 
The current treatment for BC includes surgery, chemotherapy, radiotherapy, and more recently immunotherapy. Most BC survivors in our cohort (94\%) received surgery as initial treatment for their primary BC, and surgery was associated with a lower hazard of developing any SPC. This is supported by other studies which showed that patients who did not receive surgery for BC conversely had a higher risk of any SPC including breast (13). Those who received surgery alone (without chemotherapy or radiation therapy) were also at higher risk for developing a contralateral BC (14). This may be due to increased surveillance of the contralateral breast post- $\mathrm{BC}$ treatment and suggest that a combination of surgery with or without chemotherapy and radiation therapy is the most effective treatment against BC.

We found that chemotherapy was associated with a decreased risk for breast only SPC, but increased risk of all other SPCs, which is corroborated by studies linking certain chemotherapy drugs with different types of cancers $(15,16)$. Li et al. reported that SPCs, particularly colon and lung cancers, were higher in patients who received chemotherapy for primary BC, even after adjusting for known confounders (13). Another SEER-based study determined that chemotherapy for BC patients was associated with increased incidence for several SPCs, except for some hematologic malignancies (17). Though the mechanism of how chemotherapy may inadvertently stimulate cancer growth remains largely unclear, it has been shown to be most linked to leukemia and myelodysplastic syndrome $(18,19)$.

Research regarding the risks of radiation for $\mathrm{BC}$ are also generally inconclusive. Some studies have concluded that radiation therapy for BC increases the risk for SPC in the healthy contralateral breast or ipsilateral lung compared to an unexposed population (20). Other studies have shown that only $8 \%$ of SPCs are related to radiotherapy (21). Here, we found that similar to chemotherapy, radiation therapy was associated with an increased risk of non-breast SPCs. Although the mechanisms underlying radiationinduced tumorigenesis is unclear, irradiation of surrounding tissues may cause secondary malignancies of these tissues particularly the lungs which was the second highest SPC in our cohort.

Finally, we observed significant associations between certain medications and the development of SPCs. Statins and anti-hypertensives were both associated with increased hazard of developing any SPC including breast SPC, A large population-based study determined that certain antihypertensives, including loop and thiazide diuretics, were associated with adverse BC outcomes, such as increased risk of breast SPCs, recurrence, and BC mortality $(22,23)$. Thiazide diuretics specifically are associated with insulin resistance, which has been found to be an established risk factor for $\mathrm{BC}$ and may also explain the risk associated with antihypertensives (22). While the biological mechanisms are unclear, statins have also been shown to impact cancer outcomes, with varying results for different cancer types. For example, a SEER-based study determined that statin use improved overall and lung cancer specific survival in patients with stage IV non-small cell lung cancer (NSCLC), citing in vitro studies that have demonstrated reduced proliferation, migration, and increased apoptosis of lung cancer cell lines with simvastatin use (24). Prior studies have also explored the use of metformin in cancer treatment, as it has been shown to have a potential antitumor effect $(25,26)$, though it was not significantly associated with decreased risk of SPCs in our multivariable adjusted models. 
Bisphosphonates and aromatase inhibitors were associated with decreased hazard of developing any SPC including non-breast SPCs. Bisphosphonates have been shown to decrease risk of both locoregional/distant BC recurrence or second primary BC (27). Its effect on the development of other SPCs is less well understood. However, anti-tumor properties have been shown in preclinical studies(28) and it is effective in reducing the risk of bone metastases (27). Aromatase inhibitor therapy is the gold standard for the treatment of HR positive BC in post-menopausal BC survivors (29). Preclinical studies have shown that aromatase inhibitors in combination with standard cisplatin chemotherapy for NSCLC decreases tumor progression (24). Post-menopausal hormone exposure was also associated with a reduced risk for later development of NSCLC in the general population (30).

\section{Limitations}

This study has some limitations. First, it is possible that certain SPCs may have been recurrence or metastases of primary BC. However, this was mitigated by excluding patients for whom the SPC was a $\mathrm{BC}$ diagnosed within six months of the primary $\mathrm{BC}$ diagnosis. In our adjusted analyses we also modeled all SPCs, breast only SPCs, and non-breast SPCs to isolate the effects of treatment and medications on the development of SPCs. Our cohort was limited to postmenopausal women; thus, our findings are not necessarily generalizable to premenopausal women. Postmenopausal women are at an increased risk of SPCs due to increasing age and comorbidities. As such, our results can assist in determining those who may benefit from increased cancer surveillance. We were unable adjust for other potential confounders, such as family history of cancer, and reproductive or lifestyle factors such as smoking or obesity. Finally, we do not have detailed treatment information such as type of chemotherapy or radiation therapy dose.

\section{Conclusion}

In summary, SPCs pose a threat to BC survivors, though the nuances in potential biologic and epidemiologic explanations remain unclear. Our comprehensive exploration uncovered several risk-based factors such as tumor stage, histology, medications, and comorbidities that can provide guidance to clinicians for cancer screening and prevention among postmenopausal BC survivors.

\section{Declarations}

Funding

This work was supported by the National Cancer Institute of the National Institutes of Health (T32CA225617 to SB). The content is solely the responsibility of the authors and does not necessarily represent the official views of the National Institutes of Health.

Competing Interests

The authors Stacyann Bailey, Charlotte Ezratty, Grace Mhango, and Jenny Lin have no relevant financial or non-financial interests to disclose. 


\section{Data Availability}

The data that support the findings of this study are available from NCI SEER-Medicare, but restrictions apply to the availability of these data, which were used under license for the current study, and so are not publicly available. Data are however available from the authors upon reasonable request and with permission of NCI SEER-Medicare.

\section{Ethics Approval}

This study was deemed exempt by the Mount Sinai Institutional Review Board.

Author Contributions

All authors contributed to the study conception and design. Material preparation, data collection and analysis were performed by Stacyann Bailey, Charlotte Ezratty and Grace Mhango. The first draft of the manuscript was written by Stacyann Bailey, and all authors commented on previous versions of the manuscript. All authors read and approved the final manuscript.

\section{References}

1. Cheng Y, Huang Z, Liao Q, Yu X, Jiang H, He Y et al (2020) Risk of second primary breast cancer among cancer survivors: Implications for prevention and screening practice. ; Available from: https://doi.org/10.1371/journal.pone.0232800

2. Liu Y, Dong C, Chen L (2017 Apr) The clinicopathological features of second primary cancer in patients with prior breast cancer. Medicine 96(16):e6675

3. Marcu LG, Santos A, Bezak E (2014 Jan) Risk of second primary cancer after breast cancer treatment. Eur J Cancer Care 23(1):51-64

4. Sung H, Hyun N, Leach CR, Yabroff KR, Jemal A (2020 Dec) Association of First Primary Cancer With Risk of Subsequent Primary Cancer Among Survivors of Adult-Onset Cancers in the United States. JAMA 22(24):2521

5. Li D, Weng S, Zhong C, Tang X, Zhu N, Cheng Y et al (2020) Jan Risk of Second Primary Cancers Among Long-Term Survivors of Breast Cancer.Frontiers in Oncology. 13;9.

6. Yedjou C, Tchounwou P, Payton M, Miele L, Fonseca D, Lowe L et al (2017 May) Assessing the Racial and Ethnic Disparities in Breast Cancer Mortality in the United States. Int J Environ Res Public Health $5(5): 486$

7. Li Z, Wu Q, Song J, Zhang Y, Zhu S, Sun S (2018) Risk of Second Primary Female Genital Malignancies in Women with Breast Cancer: a SEER Analysis. Hormones and Cancer. Jun 19;9(3):197-204

8. Goodwin JS (1987 Dec) The Effect of Marital Status on Stage, Treatment, and Survival of Cancer Patients. JAMA: The Journal of the American Medical Association 4(21):3125 
9. Putti TC, El-Rehim DMA, Rakha EA, Paish CE, Lee AH, Pinder SE et al (2005 Jan) Estrogen receptornegative breast carcinomas: a review of morphology and immunophenotypical analysis. Mod Pathol 27(1):26-35

10. Nahleh $Z$ Androgen receptor as a target for the treatment of hormone receptor-negative breast cancer: an unchartered territory.Future Oncology. 2008Feb; 4(1):15-21

11. Lee A, Djamgoz MBA (2018 Jan) Triple negative breast cancer: Emerging therapeutic modalities and novel combination therapies. Cancer Treat Rev 62:110-122

12. Kurian AW, McClure LA, John EM, Horn-Ross PL, Ford JM, Clarke CA (2009 Aug) Second Primary Breast Cancer Occurrence According to Hormone Receptor Status. JNCI J Natl Cancer Inst 5(15):1058-1065

13. Li Z, Wang K, Shi Y, Zhang $X$, Wen J Incidence of second primary malignancy after breast cancer and related risk factors-Is breast-conserving surgery safe? A nested case-control study.International Journal of Cancer. 2020 Jan15;146(2):352-62

14. Kirova YM, de Rycke Y, Gambotti L, Pierga J-Y, Asselain B, Fourquet A Second malignancies after breast cancer: the impact of different treatment modalities. British Journal of Cancer. $2008 \mathrm{Mar}$ 12;98(5):870-4

15. Kerr AJ, Dodwell D, McGale P, Holt F, Duane F, Mannu G et al (2022 Apr) Adjuvant and neoadjuvant breast cancer treatments: A systematic review of their effects on mortality. Cancer Treat Rev 105:102375

16. Wei J-L, Jiang Y-Z, Shao Z-M (2019 Aug) Survival and chemotherapy-related risk of second primary malignancy in breast cancer patients: a SEER-based study. Int J Clin Oncol 19(8):934-940

17. Wei J-L, Jiang Y-Z, Shao Z-M (2019 Aug) Survival and chemotherapy-related risk of second primary malignancy in breast cancer patients: a SEER-based study. Int J Clin Oncol 19(8):934-940

18. Patel SA (2019) Myelodysplastic Syndrome and Acute Myeloid Leukemia Risk Associated With Solid Tumor Chemotherapy. JAMA Oncology. Mar 1;5(3):303

19. Kaplan HG, Malmgren JA, Atwood MK (2011) Increased incidence of myelodysplastic syndrome and acute myeloid leukemia following breast cancer treatment with radiation alone or combined with chemotherapy: a registry cohort analysis 1990-2005. BMC Cancer. Dec 21;11(1):260

20. Mazonakis M, Stratakis J, Lyraraki E, Damilakis J (2019 Apr) Risk of contralateral breast and ipsilateral lung cancer induction from forward-planned IMRT for breast carcinoma. Physica Med 60:44-49

21. de Gonzalez AB, Curtis RE, Kry SF, Gilbert E, Lamart S, Berg CD et al (2011 Apr) Proportion of second cancers attributable to radiotherapy treatment in adults: a cohort study in the US SEER cancer registries. Lancet Oncol 12(4):353-360

22. Chen L, Chubak J, Boudreau DM, Barlow WE, Weiss NS, Li Cl (2017 Nov) Use of Antihypertensive Medications and Risk of Adverse Breast Cancer Outcomes in a SEER-Medicare Population. Cancer Epidemiol Biomarkers Prev 26(11):1603-1610 
23. Phadke S, Clamon G (2019 Jun) Beta blockade as adjunctive breast cancer therapy: A review. Crit Rev Oncol/Hematol 138:173-177

24. Lin JJ, Ezer N, Sigel K, Mhango G, Wisnivesky JP (2016 Sep) The effect of statins on survival in patients with stage IV lung cancer. Lung Cancer 99:137-142

25. Vancura A, Bu P, Bhagwat M, Zeng J, Vancurova I (2018 Oct) Metformin as an Anticancer Agent. Trends Pharmacol Sci 39(10):867-878

26. Lin JJ, Gallagher EJ, Sigel K, Mhango G, Galsky MD, Smith CB et al (2015 Feb) Survival of Patients with Stage IV Lung Cancer with Diabetes Treated with Metformin. Am J Respir Crit Care Med 15(4):448-454

27. Korde LA, Doody DR, Hsu L, Porter PL, Malone KE (2018 Feb) Bisphosphonate Use and Risk of Recurrence, Second Primary Breast Cancer, and Breast Cancer Mortality in a Population-Based Cohort of Breast Cancer Patients. Cancer Epidemiol Biomarkers Prev 27(2):165-173

28. Croucher P, Jagdev S, Coleman R (2003 Aug) The anti-tumor potential of zoledronic acid. The Breast 12:S30-S36

29. Osborne CK, Schiff R (2005 May) Aromatase inhibitors: Future directions. J Steroid Biochem Mol Biology 95(1-5):183-187

30. Schwartz AG, Wenzlaff AS, Prysak GM, Murphy V, Cote ML, Brooks SC et al Reproductive Factors, Hormone Use, Estrogen Receptor Expression and Risk of Non-Small-Cell Lung Cancer in Women.Journal of Clinical Oncology. 2007 Dec20;25(36):5785-92

\section{Statements and Declarations}

\section{Tables}


Table 1

Demographic and Clinical Characteristics associated with Development of Second Primary Cancer

\begin{tabular}{|c|c|c|c|}
\hline \multirow{2}{*}{$\begin{array}{l}\text { Patient Characteristics } \\
(\mathrm{N}, \%)\end{array}$} & $\begin{array}{l}\text { Second Primary Cancer } \\
\text { Development }\end{array}$ & $\begin{array}{l}\text { No Second Primary Cancer } \\
\text { Development }\end{array}$ & \multirow[t]{2}{*}{$\begin{array}{l}\mathrm{P}- \\
\text { value }\end{array}$} \\
\hline & $N=21510$ & $N=149801$ & \\
\hline \multicolumn{4}{|l|}{ Age } \\
\hline $66-69$ & $5147(12.9)$ & 34634 (87.1) & \multirow{4}{*}{$<.001$} \\
\hline $70-74$ & 6225 (13.7) & $39224(86.5)$ & \\
\hline $75-79$ & $5364(13.7)$ & 33690 (86.8) & \\
\hline$>80$ & $4774(10.2)$ & 42263 (90.6) & \\
\hline \multicolumn{4}{|l|}{ Race/Ethnicity } \\
\hline White & $18316(12.8)$ & 124813 (87.6) & \multirow{4}{*}{$<.001$} \\
\hline Black & $1595(12.1)$ & 11545 (88.2) & \\
\hline Hispanic & 794 (11.6) & 6319 (89.2) & \\
\hline Other & 805 (10.2) & $7124(90.1)$ & \\
\hline \multicolumn{4}{|l|}{ Geographic status } \\
\hline Urban & 21091 (12.6) & 146827 (87.8) & \multirow[t]{2}{*}{0.514} \\
\hline Rural & $385(12.1)$ & 2778 (88.4) & \\
\hline \multicolumn{4}{|l|}{ Income quartile } \\
\hline First quartile & $5272(12.5)$ & 37016 (88.1) & \multirow[t]{4}{*}{0.390} \\
\hline Second quartile & 5365 (12.5) & 37515 (88.0) & \\
\hline Third quartile & $5403(12.6)$ & 37381 (88.0) & \\
\hline Fourth quartile & $5442(12.8)$ & 36980 (87.2) & \\
\hline \multicolumn{4}{|l|}{ Marital Status } \\
\hline Married & $9841(12.9)$ & 66642 (87.3) & \multirow{2}{*}{$<.001$} \\
\hline Not married & 11669 (12.3) & 83159 (88.2) & \\
\hline \multicolumn{4}{|l|}{ Tumor Stage } \\
\hline Stage 0 & $4648(15.4)$ & 25601 (84.9) & \multirow{3}{*}{$\begin{array}{l}< \\
0.001\end{array}$} \\
\hline Stage I & 10015 (12.8) & 68494 (87.6) & \\
\hline Stage II & 5335 (11.4) & 41539 (89.0) & \\
\hline
\end{tabular}




\begin{tabular}{|c|c|c|c|}
\hline \multirow{2}{*}{$\begin{array}{l}\text { Patient Characteristics } \\
(\mathrm{N}, \%)\end{array}$} & $\begin{array}{l}\text { Second Primary Cancer } \\
\text { Development }\end{array}$ & $\begin{array}{l}\text { No Second Primary Cancer } \\
\text { Development }\end{array}$ & \multirow[t]{2}{*}{$\begin{array}{l}\mathrm{P} \text { - } \\
\text { value }\end{array}$} \\
\hline & $N=21510$ & $N=149801$ & \\
\hline Stage III & $33(6.6)$ & $469(94.0)$ & \\
\hline Stage IIIA & $753(10.4)$ & $6479(90.0)$ & \\
\hline Stage IIIB & $344(8.5)$ & 3728 (92) & \\
\hline Stage IIIIC & $382(9.9)$ & 3491 (91.9) & \\
\hline \multicolumn{4}{|l|}{ Tumor Histology } \\
\hline Ductal & $14571(12.4)$ & 102546 (87.9) & \multirow{3}{*}{$<.001$} \\
\hline Lobular & $1967(11.8)$ & $14723(88.3)$ & \\
\hline Other & $4972(13.2)$ & 32532 (87.1) & \\
\hline \multicolumn{4}{|l|}{$\begin{array}{l}\text { Estrogen Receptor } \\
\text { Status }\end{array}$} \\
\hline ER+ & $14675(11.6)$ & 111440 (88.6) & \multirow{2}{*}{$<.001$} \\
\hline ER- & $2821(12.5)$ & $19822(88.0)$ & \\
\hline \multicolumn{4}{|l|}{$\begin{array}{l}\text { Progesterone Receptor } \\
\text { Status }\end{array}$} \\
\hline PR+ & $12334(11.6)$ & 93917 (88.7) & \multirow[t]{2}{*}{0.009} \\
\hline PR- & 4901 (12.1) & 35604 (88.3) & \\
\hline \multicolumn{4}{|l|}{ Her2 Receptor Status } \\
\hline Her2+ & $274(4.9)$ & $5350(95.1)$ & \multirow[t]{2}{*}{0.156} \\
\hline Her2- & $2339(5.3)$ & $41621(94.5)$ & \\
\hline \multicolumn{4}{|l|}{ Breast Subtype } \\
\hline Her2+/HR+ & $188(4.7)$ & 3775 (95.2) & \multirow[t]{4}{*}{0.303} \\
\hline Her2+/HR- & $86(5.2)$ & $1561(94.7)$ & \\
\hline Her2-/HR+ & 2077 (5.3) & 37229 (94.5) & \\
\hline Triple Negative & $260(5.7)$ & 4331 (94.5) & \\
\hline \multicolumn{4}{|l|}{ Surgery } \\
\hline Yes & 20407 (12.7) & 140397 (87.6) & \multirow{2}{*}{$<0.001$} \\
\hline No & $1103(9.8)$ & 9404 (90.2) & \\
\hline
\end{tabular}




\begin{tabular}{|c|c|c|c|}
\hline \multirow{2}{*}{$\begin{array}{l}\text { Patient Characteristics } \\
(\mathrm{N}, \%)\end{array}$} & $\begin{array}{l}\text { Second Primary Cancer } \\
\text { Development }\end{array}$ & $\begin{array}{l}\text { No Second Primary Cancer } \\
\text { Development }\end{array}$ & \multirow[t]{2}{*}{$\begin{array}{l}\mathrm{P} \text { - } \\
\text { value }\end{array}$} \\
\hline & $N=21510$ & $N=149801$ & \\
\hline \multicolumn{4}{|l|}{ Chemotherapy } \\
\hline Yes & $3620(12.5)$ & $25404(87.9)$ & \multirow[t]{2}{*}{0.637} \\
\hline No & $17890(12.6)$ & $124397(87.8)$ & \\
\hline \multicolumn{4}{|l|}{ Radiotherapy } \\
\hline Yes & 9319 (13.5) & $59824(86.9)$ & \multirow{2}{*}{$\begin{array}{l}<.001 \\
0.001\end{array}$} \\
\hline No & $1219(11.9)$ & 89977 (88.4) & \\
\hline \multicolumn{4}{|l|}{$\mathrm{NCl}$ Comorbidity Index } \\
\hline$<1$ & $17422(12.9)$ & 117801 (87.5) & \multirow{3}{*}{$\begin{array}{l}<.001 \\
0.001\end{array}$} \\
\hline $1-2$ & $2538(12.1)$ & $18366(88.1)$ & \\
\hline$>2$ & $1550(10.2)$ & $13634(90.2)$ & \\
\hline
\end{tabular}


Table 2

Medications associated with the development of second primary cancers among primary breast cancer survivors

\begin{tabular}{|llll|}
\hline Medication & $\begin{array}{l}\text { Second Primary Cancer } \\
\text { Development, }(\mathrm{N}=\mathbf{2 0 , 8 3 8 )}\end{array}$ & $\begin{array}{l}\text { No Second Primary Cancer } \\
\text { Development, }(\mathbf{N}=149,801)\end{array}$ & $\begin{array}{c}\text { P- } \\
\text { value }\end{array}$ \\
\hline Statins, N (\%) & $4808(22.3)$ & $29349(19.6)$ & 0.001 \\
\hline $\begin{array}{l}\text { Antihypertensive, N } \\
(\%)\end{array}$ & $8088(37.6)$ & $47988(32.0)$ & 0.001 \\
\hline $\begin{array}{l}\text { Bisphosphonates, } \\
\text { N (\%) }\end{array}$ & $1521(7.1)$ & $9300(6.2)$ & $<$ \\
\hline $\begin{array}{l}\text { Aromatase } \\
\text { Inhibitor, N (\%) }\end{array}$ & $679(3.2)$ & $10523(7.0)$ & 0.001 \\
\hline $\begin{array}{l}\text { Metformin, N (\%) } \\
\text { Insulin, N (\%) }\end{array}$ & $1291(6.0)$ & $7636(5.1)$ & 0.001 \\
\hline $\begin{array}{l}\text { Thiazolidinediones, } \\
\text { N (\%) }\end{array}$ & $238(1.1)$ & $3779(2.5)$ & 0.001 \\
\hline $\begin{array}{l}\text { SGLT-2 Inhibitors, N } \\
(\%)\end{array}$ & $3(0.01)$ & $1337(0.9)$ & 0.001 \\
\hline $\begin{array}{l}\text { DPP-4 Inhibitors, N } \\
(\%)\end{array}$ & $278(1.3)$ & $110(0.1)$ & 0.002 \\
\hline $\begin{array}{l}\text { GLP-1 Agonists, N } \\
(\%)\end{array}$ & $38(0.2)$ & $1793(1.2)$ & 0.002 \\
\hline
\end{tabular}


Table 3

Multivariable Cox proportional cause-specific hazard models to evaluate the effects of covariates on the rate of second primary cancer development among primary breast cancer survivors.

\begin{tabular}{|c|c|c|c|}
\hline Patient Characteristic & $\begin{array}{l}\text { All SPCs HR (95\% } \\
\text { Cl) }\end{array}$ & $\begin{array}{l}\text { Breast Only SPCs* } \\
\text { HR }(95 \% \mathrm{Cl})\end{array}$ & $\begin{array}{l}\text { Non-Breast SPCs* } \\
\text { HR }(95 \% \mathrm{Cl})\end{array}$ \\
\hline \multicolumn{4}{|l|}{ Age (yrs) (REF = 66-69) } \\
\hline $70-74$ & $\begin{array}{l}1.078(1.038- \\
1.118)^{\star}\end{array}$ & $\begin{array}{l}0.990(0.926- \\
1.059)\end{array}$ & $\begin{array}{l}1.117(1.068- \\
1.168)^{\star}\end{array}$ \\
\hline $75-79$ & $\begin{array}{l}1.121(1.078- \\
1.165)^{\star}\end{array}$ & $\begin{array}{l}0.957(0.891- \\
1.029)\end{array}$ & $\begin{array}{l}1.187(1.133- \\
1.243)^{\star}\end{array}$ \\
\hline$\geq 80$ & $\begin{array}{l}1.056(1.012- \\
1.101)^{\star}\end{array}$ & $\begin{array}{l}0.820(0.757- \\
0.888)^{\star}\end{array}$ & $\begin{array}{l}1.127(1.072- \\
1.184)^{\star}\end{array}$ \\
\hline \multicolumn{4}{|l|}{ Race/Ethnicity } \\
\hline White & REF & REF & REF \\
\hline Black & $\begin{array}{l}0.952(0.903- \\
1.005)\end{array}$ & $\begin{array}{l}1.071(0.972- \\
1.179)\end{array}$ & $\begin{array}{l}0.907(0.851- \\
0.967)^{\star}\end{array}$ \\
\hline Hispanic & $\begin{array}{l}0.832(0.774- \\
0.893)^{\star}\end{array}$ & $\begin{array}{l}0.821(0.717- \\
0.939)^{\star}\end{array}$ & $\begin{array}{l}0.819(0.752- \\
0.891)^{\star}\end{array}$ \\
\hline Other & $\begin{array}{l}0.799(0.745- \\
0.859)^{\star}\end{array}$ & $\begin{array}{l}0.823(0.723- \\
0.936)^{\star}\end{array}$ & $\begin{array}{l}0.776(0.712- \\
0.845)^{\star}\end{array}$ \\
\hline \multicolumn{4}{|l|}{ Marital Status } \\
\hline Married & $\begin{array}{l}0.985(0.957- \\
1.013)\end{array}$ & $\begin{array}{l}1.035(0.982- \\
1.091)\end{array}$ & $\begin{array}{l}0.969(0.938- \\
1.002)\end{array}$ \\
\hline \multicolumn{4}{|l|}{ Income Quartile } \\
\hline First (Lowest) & REF & REF & REF \\
\hline Second & $\begin{array}{l}1.023(0.984- \\
1.063)\end{array}$ & $\begin{array}{l}1.036(0.963- \\
1.114)\end{array}$ & $\begin{array}{l}1.020(0.975- \\
1.067)\end{array}$ \\
\hline Third & $\begin{array}{l}1.047(1.007- \\
1.088)^{\star}\end{array}$ & $\begin{array}{l}1.084(1.008- \\
1.167)^{\star}\end{array}$ & $\begin{array}{l}1.034(0.988- \\
1.082)\end{array}$ \\
\hline Fourth (Highest) & $\begin{array}{l}1.066(1.025- \\
1.108)^{\star}\end{array}$ & $\begin{array}{l}1.095(1.017- \\
1.179)^{\star}\end{array}$ & $\begin{array}{l}1.057(1.010- \\
1.107)^{\star}\end{array}$ \\
\hline \multicolumn{4}{|c|}{ Geographic Residence (REF = urban) } \\
\hline Rural & $\begin{array}{l}0.943(0.852- \\
1.044)\end{array}$ & $\begin{array}{l}0.997(0.826- \\
1.204)\end{array}$ & $\begin{array}{l}0.921(0.816- \\
1.040)\end{array}$ \\
\hline \multicolumn{4}{|l|}{ Breast Cancer Stage } \\
\hline ¥Insufficient number of & & & \\
\hline
\end{tabular}




\begin{tabular}{|c|c|c|c|}
\hline Patient Characteristic & $\begin{array}{l}\text { All SPCs HR (95\% } \\
\text { Cl) }\end{array}$ & $\begin{array}{l}\text { Breast Only SPCs* } \\
\text { HR }(95 \% \mathrm{Cl})\end{array}$ & $\begin{array}{l}\text { Non-Breast SPCs* } \\
\text { HR }(95 \% \mathrm{Cl})\end{array}$ \\
\hline Stage I & REF & REF & REF \\
\hline Stage 0 & $\begin{array}{l}1.094(1.052- \\
1.138)^{\star}\end{array}$ & $\begin{array}{l}1.434(1.339- \\
1.536)^{\star}\end{array}$ & $\begin{array}{l}0.948(0.903- \\
0.995)^{\star}\end{array}$ \\
\hline Stage II & $\begin{array}{l}0.999(0.964- \\
1.035)\end{array}$ & $\begin{array}{l}0.886(0.825- \\
0.952)^{\star}\end{array}$ & $\begin{array}{l}1.031(0.989- \\
1.073)\end{array}$ \\
\hline Stage III & $\begin{array}{l}0.845(0.599- \\
1.191)\end{array}$ & $\begin{array}{l}1.156(0.637- \\
2.098)\end{array}$ & $\begin{array}{l}0.725(0.476- \\
1.103)\end{array}$ \\
\hline Stage IIIA & $\begin{array}{l}1.009(0.934- \\
1.091)\end{array}$ & $\begin{array}{l}0.827(0.699- \\
0.979)^{\star}\end{array}$ & $\begin{array}{l}1.054(0.966- \\
1.151)\end{array}$ \\
\hline Stage IIIB & $\begin{array}{l}1.076(0.963- \\
1.202)\end{array}$ & $\begin{array}{l}1.081(0.864- \\
1.353)\end{array}$ & $\begin{array}{l}1.052(0.926- \\
1.196)\end{array}$ \\
\hline Stage IIIC & $\begin{array}{l}1.169(1.051- \\
1.300)^{*}\end{array}$ & $\begin{array}{l}1.262(1.029- \\
1.549)^{\star}\end{array}$ & $\begin{array}{l}1.123(0.992- \\
1.271)\end{array}$ \\
\hline \multicolumn{4}{|l|}{ Tumor Histology } \\
\hline Ductal & REF & REF & REF \\
\hline Lobular & $\begin{array}{l}0.972(0.926- \\
1.019)\end{array}$ & $\begin{array}{l}1.133(1.037- \\
1.237)^{\star}\end{array}$ & $\begin{array}{l}0.914(0.864- \\
0.968)^{\star}\end{array}$ \\
\hline Other & $\begin{array}{l}1.023(0.990- \\
1.057)\end{array}$ & $\begin{array}{l}1.085(1.022- \\
1.153)^{\star}\end{array}$ & $\begin{array}{l}1.003(0.964- \\
1.043)\end{array}$ \\
\hline \multicolumn{4}{|c|}{ ER Status (REF = ER Positive) } \\
\hline ER Negative & $\begin{array}{l}1.130(1.071- \\
1.192)^{\star}\end{array}$ & $\begin{array}{l}1.442(1.304- \\
1.595)^{\star}\end{array}$ & $\begin{array}{l}1.032(0.969- \\
1.100)\end{array}$ \\
\hline \multicolumn{4}{|c|}{ PR Status (REF = PR Positive) } \\
\hline PR Negative & $\begin{array}{l}0.996(0.954- \\
1.040)\end{array}$ & $\begin{array}{l}0.971(0.892- \\
1.058)\end{array}$ & $\begin{array}{l}1.006(0.957- \\
1.058)\end{array}$ \\
\hline \multicolumn{4}{|l|}{ Comorbidity Index } \\
\hline $0.00-1.00$ & REF & REF & REF \\
\hline $1.01-2.00$ & $\begin{array}{l}0.780(0.738- \\
0.824)^{\star}\end{array}$ & $\begin{array}{l}0.701(0.629- \\
0.781)^{\star}\end{array}$ & $\begin{array}{l}0.779(0.730- \\
0.830)^{\star}\end{array}$ \\
\hline$>2.00$ & $\begin{array}{l}0.735(0.690- \\
0.784)^{\star}\end{array}$ & $\begin{array}{l}0.697(0.612- \\
0.794)^{\star}\end{array}$ & $\begin{array}{l}0.699(0.649- \\
0.812)^{\star}\end{array}$ \\
\hline Comorbidities & & & \\
\hline
\end{tabular}




\begin{tabular}{|c|c|c|c|}
\hline Patient Characteristic & $\begin{array}{l}\text { All SPCs HR (95\% } \\
\text { Cl) }\end{array}$ & $\begin{array}{l}\text { Breast Only SPCs* } \\
\text { HR }(95 \% \mathrm{Cl})\end{array}$ & $\begin{array}{l}\text { Non-Breast SPCs* } \\
\text { HR }(95 \% \mathrm{Cl})\end{array}$ \\
\hline Diabetes & $\begin{array}{l}1.363(1.303- \\
1.426)^{\star}\end{array}$ & $\begin{array}{l}1.277(1.168- \\
1.369)^{\star}\end{array}$ & $\begin{array}{l}1.443(1.369- \\
1.521)^{\star}\end{array}$ \\
\hline Renal Disease & $\begin{array}{l}1.405(1.333- \\
1.481)^{\star}\end{array}$ & $\begin{array}{l}1.320(1.183- \\
1.474)^{\star}\end{array}$ & $\begin{array}{l}1.485(1.398- \\
1.577)^{\star}\end{array}$ \\
\hline $\begin{array}{l}\text { Chronic Obstructive Pulmonary } \\
\text { Disease }\end{array}$ & $\begin{array}{l}1.760(1.699- \\
1.824)^{\star}\end{array}$ & $\begin{array}{l}1.223(1.132- \\
1.321)^{\star}\end{array}$ & $\begin{array}{l}2.032(1.953- \\
2.115)^{\star}\end{array}$ \\
\hline \multicolumn{4}{|l|}{ Cancer Treatment } \\
\hline Surgery & $\begin{array}{l}0.743(0.698- \\
0.791)^{\star}\end{array}$ & $\begin{array}{l}0.714(0.636- \\
0.802)^{\star}\end{array}$ & $\begin{array}{l}0.753(0.699- \\
0.812)^{\star}\end{array}$ \\
\hline Radiation Therapy & $\begin{array}{l}1.024(0.995- \\
1.055)\end{array}$ & $\begin{array}{l}0.980(0.928- \\
1.036)\end{array}$ & $\begin{array}{l}1.053(1.017- \\
1.090)^{*}\end{array}$ \\
\hline Chemotherapy & $\begin{array}{l}1.031(0.987- \\
1.078)\end{array}$ & $\begin{array}{l}0.896(0.820- \\
0.978)^{\star}\end{array}$ & $\begin{array}{l}1.097(1.043- \\
1.154)^{\star}\end{array}$ \\
\hline \multicolumn{4}{|l|}{ Medications } \\
\hline Aromatase Inhibitor & $\begin{array}{l}0.620(0.573- \\
0.671)^{\star}\end{array}$ & $\begin{array}{l}0.467(0.393- \\
0.554)^{\star}\end{array}$ & $\begin{array}{l}0.635(0.581- \\
0.694)^{\star}\end{array}$ \\
\hline Statins & $\begin{array}{l}1.066(1.023- \\
1.110)^{\star}\end{array}$ & $\begin{array}{l}1.131(1.048- \\
1.221)^{\star}\end{array}$ & $\begin{array}{l}1.055(1.005- \\
1.108)^{\star}\end{array}$ \\
\hline Anti-hypertensives & $\begin{array}{l}1.569(1.512- \\
1.627)^{\star}\end{array}$ & $\begin{array}{l}1.978(1.845- \\
2.120)^{\star}\end{array}$ & $\begin{array}{l}1.530(1.464- \\
1.598)^{\star}\end{array}$ \\
\hline Bisphosphonates & $\begin{array}{l}0.905(0.857- \\
0.956)^{\star}\end{array}$ & $\begin{array}{l}0.898(0.812- \\
0.993)^{\star}\end{array}$ & $\begin{array}{l}0.892(0.836- \\
0.952)^{\star}\end{array}$ \\
\hline Metformin & $\begin{array}{l}1.054(0.986- \\
1.127)\end{array}$ & $\begin{array}{l}1.041(0.915- \\
1.185)\end{array}$ & $\begin{array}{l}1.072(0.992- \\
1.159)\end{array}$ \\
\hline Insulin & $\begin{array}{l}0.908(0.898- \\
1.071)\end{array}$ & $\begin{array}{l}1.097(0.926- \\
1.300)\end{array}$ & $\begin{array}{l}0.944(0.851- \\
1.047)\end{array}$ \\
\hline Thiazolidinediones & $\begin{array}{l}0.816(0.714- \\
0.931)^{\star}\end{array}$ & $\begin{array}{l}0.651(0.496- \\
0.853)^{\star}\end{array}$ & $\begin{array}{l}0.870(0.748- \\
1.013)\end{array}$ \\
\hline SGLT2-Inhibitors & $\begin{array}{l}0.388(0.125- \\
1.206)\end{array}$ & $\begin{array}{l}0.000(0.000- \\
1.55 \mathrm{E} 39)^{¥}\end{array}$ & $\begin{array}{l}0.470(0.151- \\
1.464)\end{array}$ \\
\hline DDP4-Inhibitors & $\begin{array}{l}1.057(0.933- \\
1.197)\end{array}$ & $\begin{array}{l}1.208(0.955- \\
1.529)\end{array}$ & $\begin{array}{l}1.043(0.900- \\
1.208)\end{array}$ \\
\hline GLP1-Agonists & $\begin{array}{l}1.289(0.932- \\
1.784)\end{array}$ & $\begin{array}{l}1.265(0.690- \\
2.320)\end{array}$ & $\begin{array}{l}1.311(0.892- \\
1.927)\end{array}$ \\
\hline
\end{tabular}




\section{Figures}

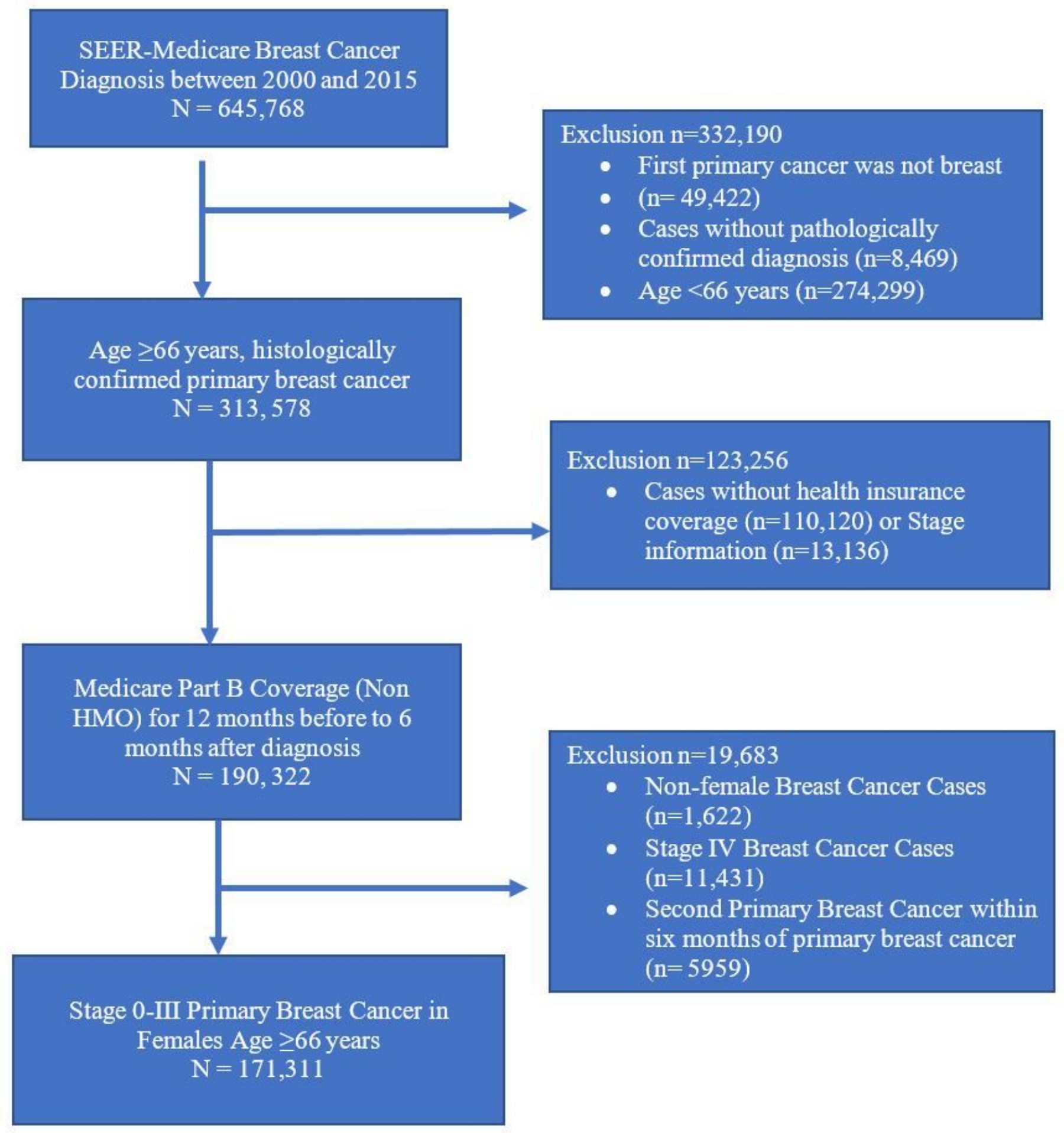

\section{Figure 1}

Summary of the final cohort selection. $\mathrm{HMO}=$ health maintenance organization; Part $\mathrm{B}=$ supplemental insurance 


\section{Types of Second Primary Cancers}

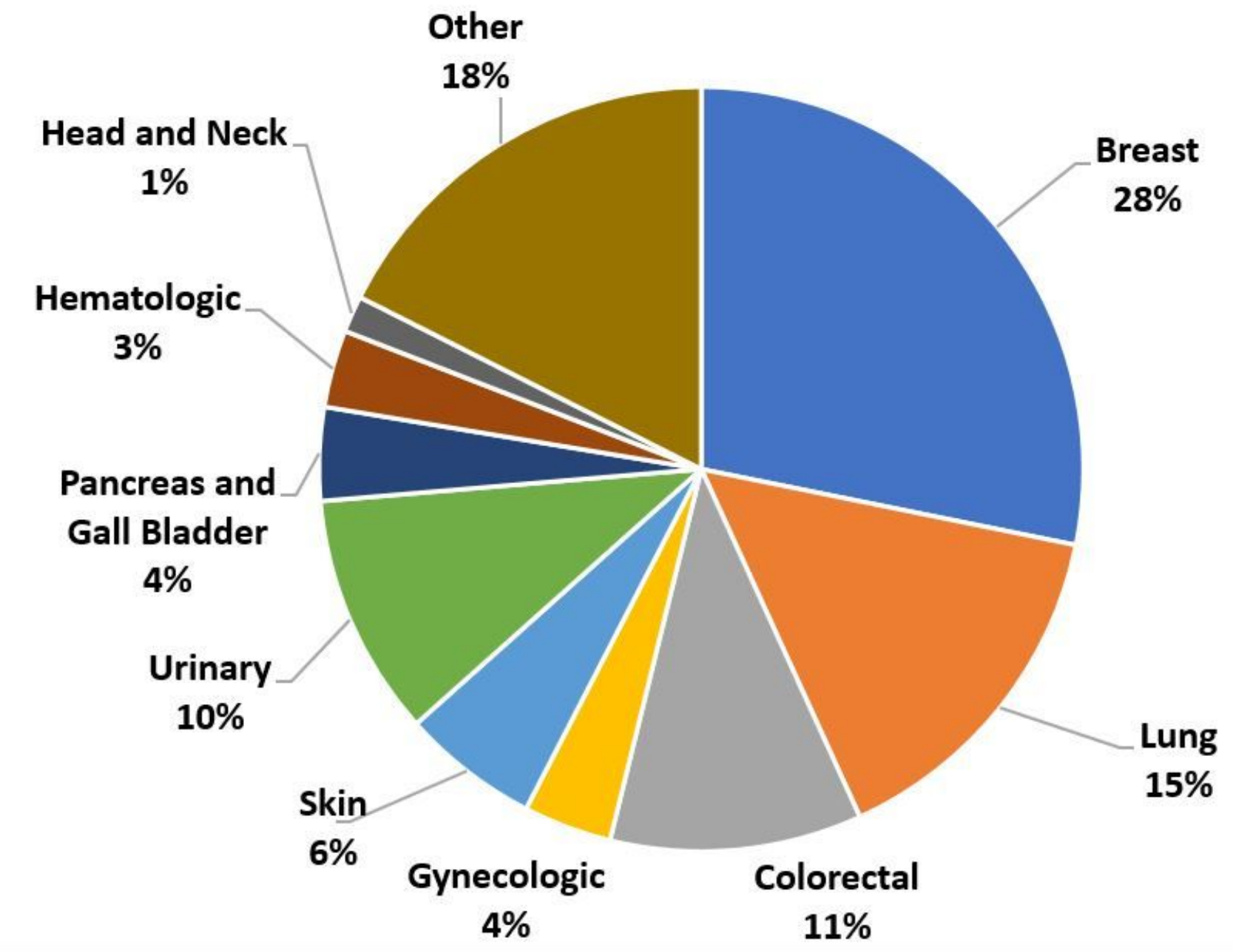

Figure 2

Types of second primary cancers among primary breast cancer patients. Other includes Liver, GI, Soft Tissue, Bone, Endocrine, Brain and CNS, and other 